\title{
Sheet-Like Microfossils From Hydrothermally Influenced Basinal Cherts of the Lower Cambrian (Terreneuvian) Niutitang Formation, Guizhou, South China
}

\section{Citation}

Yin, Lei-Ming, Tenger Borjigin, Andrew H. Knoll, Li-Zeng Bian, Xiao-Min Xie, Fang Bao, and ZhiJi Ou. 2017. Sheet-like Microfossils from Hydrothermally Influenced Basinal Cherts of the Lower Cambrian (Terreneuvian) Niutitang Formation, Guizhou, South China. Palaeoworld 26, no. 1: $1-11$.

\section{Published Version}

doi:10.1016/j.palwor.2016.01.005

\section{Permanent link}

http://nrs.harvard.edu/urn-3:HUL.InstRepos:41531370

\section{Terms of Use}

This article was downloaded from Harvard University's DASH repository, and is made available under the terms and conditions applicable to Open Access Policy Articles, as set forth at http:// nrs.harvard.edu/urn-3:HUL.InstRepos:dash.current.terms-of-use\#OAP

\section{Share Your Story}

The Harvard community has made this article openly available.

Please share how this access benefits you. Submit a story. 
Sheet-like microfossils from hydrothermally influenced basinal cherts of the Lower

Cambrian (Terreneuvian) Niutitang Formation, Guizhou, south China

Lei-Ming Yin ${ }^{1 \times}$, Tenger Borjigin² , Andrew H. Knoll ${ }^{3}$, Li-Zeng Bian ${ }^{4}$, Xiao-Min Xie², Fang Bao² ${ }^{2}$ Zhi-Ji Ou ${ }^{5}$

1.State Key Laboratory of Palaeobiology and Stratigraphy, Nanjing Institute of Geology and Palaeontology, Chinese Academy of Sciences, Nanjing 210008, Jiangsu, China

2. Key Laboratory of Petroleum Accumulation Mechanisms, Wuxi Research Institute of Petroleum Geology, SINOPEC, Wuxi 214151, Jiangsu, China

3. Department of Organismic and Evolutionary Biology, Harvard University, Cambridge, Massachusetts 02138, USA.

4. School of Earth Sciences and Engineering, Nanjing University, Nanjing 210008, Jiangsu, China

5. Tromsø University Museum, Natural Sciences, UiTThe Arctic University of Norway, N-9037 Tromsø, Norway

\section{Abstract}

Early diagenetic cherts in basinal shales of the lower Cambrian (Terreneuvian) Niutitang Formation, exposed in the Yangtiao section, Majiang, Guizhou Province, China, contain abundant sheet-like microfossils. The sheets are carbonaceous, rich in complex aromatic molecules, sinuously folded and, commonly, tightly enrolled. Their regular thickness, lack of evidence for cellular structure, occasional ornamentation by finger- or hair-like projections, and infrequent attachment to one another eliminate ripped up microbial mats and blade-like algae as biological sources. More likely, the Niutitang sheets represent surficial coverings of animals. In the absence of information on sheet morphology, it is difficult to constrain systematic interpretation further, but other Ediacaran and Cambrian fossils suggest that a cnidarian affiliation is plausible. The siliceous sequence of the lowest Cambrian Niutitang Formation was deposited under a relatively stable anaerobic environment, episodically influenced by hydrothermal fluids. Thus, it is probable that the sheets were transported into the basin from oxic shelves or sank to the bottom from oxygenated surface waters. In either event, these problematic remains provide new evidence of biological diversity in early Cambrian oceans.

Keywords: Early Cambrian, Niutitang Formation, hydrothermal sediments, sheet-like fossils. 


\section{Introduction}

Lower Cambrian sedimentary rocks are widespread in south China, and these have proven a treasure trove of paleobiological information. In particular, phosphate- and chert-rich facies have preserved diverse macro- and microfossils, including small shelly fossils, animal embryos, algae and organic-walled resting cells (Qian and Bengtson, 1989; Yin, 1997; Yao et al., 2005; Steiner et al., 2007). And hydrothermally influenced shales and exhalative ore bodies in Guizhou Province additionally preserve sulfur bacteria, sponge spicules, and bilaterian compressions (Steiner et al., 2001; Yang et al., 2005).

Here we report abundant and commonly enrolled organic sheets preserved in silicified beds of lower Niutitang Formation in the Yangtiao section of eastern Guizhou, south China. We interpret these remains as probable animal cuticle, but beyond this, their affinities remain problematic. Nonetheless, they contribute to a growing body of data on the biological diversity and ecology of basinal, hydrothermally influenced environments as the Cambrian Period unfolded.

Fig. 1. Sketch map showing location of the Yangtiao section of the lower Cambrian (Terreneuvian) Niutitang Formation in eastern Guizhou, China.

Fig. 2. Generalized stratigraphic section of the Niutitang Formation in the Yangtiao section (A) showing siliceous sequences, with detailed sample positions of cherts indicated by triangles (B). Black spiral indicates the stratigraphic distribution of sheet-like microfossils.

\section{Geological Setting}

Lower Cambrian strata in south China record the extensive flooding of a continental platform and margin, with shallow marine facies - and evidence of episodic exposure - to the west and relatively deep basinal environments to the southeast (Li and Gao, 1995; Steiner et al., 2001; Luo et al., 2003). Basinal black shales are widely exposed in the Yangtze region; these shales host Ni-Mo-PGE polymetallic sulfide, phosphorite, and barite ores in the Yangtze Platform, and so have been thoroughly investigated (Fan, 1987; Wang et al., 1992).

The Yangtiao section of Majiang, located in Guizhou Province (Fig. 1), exemplifies these deeper marine facies (Li and Gao, 1995). The lower Cambrian sequences of the section include the Niutitang Formation and the overlying Jiumenchong Formation, which lie unconformably on dolostone of the Ediacaran Dengying Formation and have a total thickness of $76 \mathrm{~m}$ 
(Fig. 2A). At the base of the Niutitang Formation, interbedded cherts and siliceous shale containing phosphorite nodules form a distinctive unit up to $2.5 \mathrm{~m}$ thick (Fig. 2B). Consistent with basinal deposition, the beds are characterized by parallel lamination, with little evidence of wave influence. Fe-speciation studies indicate that subsurface anoxia persisted into the Cambrian in this region (Feng et al., 2014), as it did elsewhere (Sperling et al., 2015). Elemental analysis of 70 Niutitang shales samples indicates trace element enrichment above crustal values (Taylor and McLennan, 1985, 1995): P (mean 4.16

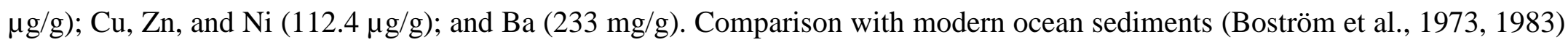
suggests that this enrichment is most readily explained by hydrothermal input into the Niutitang basin (Steiner et al., 2001; Jiang et al., 2003, 2007; Zhou and Jiang , 2009; Pi et al., 2013; Li et al., 2015). A high Ba/Sr ratio -- 4.64-363 by weight -also indicates strong hydrothermal influence during deposition, consistent, as well, with analyses of rare earth elements (REE) and sulfur isotopes (Sterner et al., 2001). Further consistent with this interpretation, beds immediately above the siliceous shale succession host Ni-Mo sulfide ores thought to have been sourced by deep hydrothermal fluids (Jiang et al., 2007). The organic content of these shales is variable, but commonly high $(0.6-19.6 \%$; mean $=3.7 \%)$.

Basal Niutitang cherts preserve abundant and diverse microfossils, including sponge spicules, benthic algae and organic-walled resting cells (acritarchs) of taxa restricted to the Meishucunian Stage (Yin, 1986; Yao et al., 2005). These have supported correlation of the lower Meishucunian succession to carbonates of the Anabarites trisulcatus-Protohertzina anabarica-Protohertzina unguliformis small shelly fossil assemblage zone in Siberia (Yao et al., 2005; Steiner et al., 2007). In Yunnan, tuffs in the lower Meishucunian Liuchapo Formation, which underlie Niutitang shales, have yielded a U-Pb age of 536.3 \pm 5.5 Ma (Chen et al., 2009), consistent with zircon dates of 536.7 $\pm 5.5 \mathrm{Ma}$ (Zhu et al., 2009) and536.5 $\pm 2.5 \mathrm{Ma}$ (Sawaki et al., 2008) for tuffs in Yunnan thought to be correlative. Recently, Chen et al. (2015) analyzed zircons in a tuff

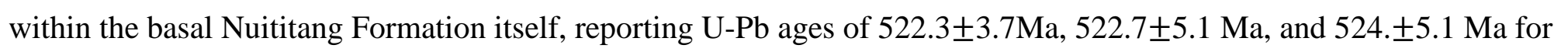
samples from three different localities. This date is a bit younger than that commonly suggested for the Anabarites trisulcatus-Protohertzina anabarica-Protohertzina unguliformis zone in Siberia, but this may reflect ecology and environment as much as evolutionary change (e.g., Landing et al., 2013).

Fig. 3.Sheet-like fossil remains in thin section, viewed under the optical microscope. A, shows the complex folding characteristic of this population; thin section No. MY15-(3). B and C (enlarged) sinuously folded sheets showing connections between sheets (arrows in C), the presence of detrital organic material within a central cavit,y and the absence of detritus around other sheets; No. MY37-(1). D, enlargement showing the regular, non-cellular morphology of sheets viewed in cross-section and the tendency of sheets to become enrolled. (E) Enlargement of central cavity in C, showing particulate internal organic materials.

Fig. 4. A, B, Fine filaments that ornament one face of a sheet-like microfossil; No. NY15-(2). C, D, Tightly enrolled specimen forming a tight spiral in cross section - note apparent disassociation into a thin surface membrane and a thicker subjacent structure; No. MY33-(1).E, F, Enrolled sheets showing finger-like organic projections from one surface; No.MY48-(4); arrow in (F) indicates a projection in cross-section. 


\section{Material and Methods}

The sheet-like fossils described here come from thin sections of cherts in the lowermost Niutitang Formation in the Yangtiao section, Guizhou, south China. The sheet-like forms begin $57 \mathrm{~cm}$ above the base of the formation and ends at $245 \mathrm{~cm}$; they are most common between 90 and 190cm above the base of the formation. Maceration in hydrofluoric acid did not recover intact sheets; here, as elsewhere where organic remains are preserved in chert, morphologically coherent fossils commonly consist of fine particles on the nanoscale (Knoll, 1985). SEM of fresh chert surfaces and Atomic Force Microscopy (ATM) provided additional information on morphology, while computerized energy-dispersive X-ray micro-analysis and in situ laser Raman analysis constrained the chemical composition of the sheets.

\section{Results}

Sheet-like structures are common in thin sections of Niutitang cherts. Viewed in cross section, the sheets are regular and thin, with sharp boundaries on both faces and squared-off ends (Figs. 3-5). All specimens exhibit sinuous folds, and commonly, the sheets are enrolled to form a tight spiral 4.5-12 $\mu \mathrm{m}$ (mean $\sim 8 \mu \mathrm{m}$ ) wide in cross-section (Figs.4C, D; 5A, E). In a few cases, sheets are larger $(>100 \mu \mathrm{m})$ and thinner, exhibiting a chagrinate, membrane-like appearance (Fig.5A,B,F,G). In general, sheet length is highly variable, ranging from tens or hundreds of microns to as much as several millimeters (Fig. 3A, B). The morphological features preserved in thin section indicate that the original materials were pliant, not stiff. Importantly, some specimens show attachment sites between two of more sheets, with loop- or tube- like extensions from other sheets (Fig. 4C,D). Also, some sheets form apparently enclosed spaces that contain organic detritus, including possible microfossils (Fig.3E). A few rolled-up specimens display sparsely distributed, finger-like projections up to $300 \mu \mathrm{m}$ long and $25 \mu \mathrm{m}$ in cross-sectional diameter (Fig. 4E, F), sparsely distributed dentate protuberances (Fig. 5C, D) or numerous fine filaments on one side (Fig. 4A, B); these suggest that more than one species may have contributed sheets to this assemblage. AFM (Atomic Force Microscopy) shows that on the nanoscale sheets have irregular pittings of uncertain origin (Fig. 7).

Sheets are commonly associated with more diaphanous membrane-like structures (Fig. 5A, B). The surfaces of these membranous features are ornamented with fine granules or spines (Fig. 5B, F,G). Energy-dispersive X-ray analysis confirms that sheets are enriched in carbon relative to surrounding matrix (Table 1). Raman spectroscopy further reveals that the sheet-like forms all contain aromatic rings displaying a defect ' $D$ ' peak around $1350 \mathrm{~cm}-1$, a sharp graphite 'G' peak around $1600 \mathrm{~cm}-1$, and secondary peak at $2700 \mathrm{~cm}-1$ (Fig. 8). This tells us that the organic material comprising the sheets contains extended aromatic structures, such as those formed by polycyclic aromatic hydrocarbons. Although this signature indicates extensive organic diagenesis, it does little to constrain original composition. 
Fig.5. A, B, Sheet-like fossil remains, No. 33-(1); (B) is an enlargement of (A), highlighting the finely granular texture of the membranous surface. C, D, enrolled sheets showing small dentate prominences on one side; No. MY33-(1). E, a pair of tightly enrolled sheets; No.15-(1). F, G, intimately interfolded (and possibly connected) sheets showing a finely granular surface; No. MY37-(1).

Fig. 6. SEM images of sheet-like fossil remains preserved in situ in chert. A, Membrane-like specimen under lower SEM magnification; No. MY 33-(1). B-G, Details of the specimen shown in A

Table1. Results of the energy-dispersive X-ray micro-analysis (EDX) for sheet-like specimens (A) and surrounding rock matrix (B).

Fig.7. AFM (atomic force microscope) photos of rolling sheet-like specimens. A, B, $\mathrm{C}$, show the thickness of sheet and its plastic character; arrows in (A) indicate testing positions for (B) and (C).

Fig. 8. In situ laser Raman analyses of sheet-like specimens. Analyzed specimens show prominent vibrational bands at $\backsim 1,350 \mathrm{~cm}^{-1}$ ("D" band) and $\backsim 1,600 \mathrm{~cm}^{-1}$ (“G” band), establishing the carbonaceous (kerogenous) composition of the fossils.

\section{Discussion}

The list of biological structures that might have given rise to the Niutitang sheets is pretty much limited to ripped-up microbial mat fragments, blade-like algae, and cuticle or other resistant surfaces of animals. Microbial mat laminae are known to become enrolled, forming what geologists refer to as rip-up structures (e.g., Noffke, 2010, Beraldi-Campesiet al., 2014), but several characters rule out mat fragments as sources of the Niutitang structures: the mats are highly regular in thickness, with sharp boundaries and a suggestion of internal structure (Fig. 4E,F); they also have finger-like morphological projections and are sometimes attached to one another at a high angle. Both individually and collectively, these features make a mat source unlikely. Similarly, the absence of evidence for cellular structure in the sheets casts doubt on their interpretation as algae. And, finally, the Niutitang fossils predate known occurrences of embryophyte cuticle (Gensel, 2008) and the radiation of larger fungi capable in principle of producing sheet-like surficial features (Lücking et al., 2009); both of these groups, of course, 
inhabit terrestrial environments.

This leaves decay-resistant surfaces synthesized by animals. Cuticle is widely distributed among extant animals, occurring in the Cnidaria as well as bilaterian phyla, especially ecdysozoans (e.g., Bereiter-Hahn et al., 1984). The cuticles found in different phyla are biochemically heterogeneous, ranging from lipid-associated proteins to chitin. Both cuticle rigidity and preservation potential are enhanced by sclerotization, but under favorable circumstances a range of cuticle types can preserve. In addition to original biological composition, Briggs (1999) specifically cited depositional environment, enclosing lithology and the diagenetic production of aliphatic compounds as key factors in the morphological preservation of cuticle. An impressive an impressive diversity of arthropod, pripaulid and other cuticle has been reported from fine-grained Cambrian rocks (Smith et al., 2015; Harvey et al., 2012; Harvey and Pedder, 2013), and one might imagine that the anoxic bottom waters and early diagenetic chert emplacement in the Niutitang basin might also have favored cuticle preservation. If cuticle, the Niutitang sheets could not have been heavily sclerotized, given their flexibility, but originally flexible cuticle has been reported from Cambrian phosphorites (Zhao and Bengtson, 1999) and shales (Harvey et al., 2012). Invertebrate cuticle can also contain and preserve hair- and finger-like projections similar to those observed in the Niutitang population (e.g., Urbancik et al., 1996). While morphological structure can be taxonomically diagnostic for cuticle or integumentary remains preserved in three dimensions, original chemical composition, whether protein- or chitin-based, is rarely preserved (Stankiewicz et al., 1997).

Whereas animals appear to be the most likely source of the Niutitang sheets, finer-scale systematic placement is difficult in the absence of clear morphology. The fossil sheets occur at about the same stratigraphic level as the oldest known body fossils of arthropods and priapulids (Steiner et al. 2004; Liu et al. 2014; Zhang et al. 2015), and tubular carbonaceous fossils in Ediacaran and Cambrian rocks suggest other possibilities, for example, the tubular remains of sabelliditids (Sokolov, 1965; Yang et al., 1980; Urbanek and Mierzejewska, 1983; Sarma et al., 1992; Moczydłowska et al., 2014). Generally interpreted in terms of extant, tube-forming sabellid annelids, these carbonaceous remain are locally common lower Cambrian shales and conceivably might split longitudinally to produce plaint sheets. An argument against such an interpretation is the observed complexity of sabelliditid tubes as observed using TEM (Urbanek and Mierzejewska, 1983; Moczydłowska et al., 2014); moreover, the Niutitang sheets show no evidence of the rhythmical annulation characteristic of sablliditids.

More promising are the chitinous peridermal tubes constructed by some coronate scyphozoans (Werner, 1971; Chapman and Werner, 1972; Morandini and Jarms, 2010), which have been compared to the widely distributed Ediacaran fossil Cloudina and other non-calcified remains of similar age. As in the case of sabelliditids, interpretation of Niutitang sheets as cnidarian peridermal tubes requires that the tubes split and accumulate in sediments as sheets and that some Cambrian taxa lacked the rhythmic annulations commonly (but not invariably; Jarms, 1991) found in modern examples. In favor of at least the broad form of this hypothesis is the connected sheets as observed in Fig. 5C, D; a number of Ediacaran tubes show evidence of budding, a feature used to suggest cnidarian affinities (e.g., Cortijo et al., 2015, and references therein). In particular, the carbonaceous fossil Sinotubulites has flexible thin walls that closely resemble the Niutitang sheets in thin section (Chen et al., 2008). More generally, smooth carbonaceous tubes are common in Ediacaran (e.g., Cohen et al., 2010) and Lower Paleozoic (e.g., Vaniten et al., 2013; Stewart et al., 2015) shales; many but not all of these are interpreted as probable cnidarians. Such a 
hypothesis could be tested in future, should additional sheets with preserved microstructure be discovered (see, for example, Cai et al., 2015).

The Niutitang sheets are preserved in mud that lay beneath episodically anoxic bottom waters (Scott et al., 2008; Zhu et al., 2014;Jones and Manning, 1994; Piper, 1994; Pattan et al., 2005) and so were probably transported from more shallow, oxygenated environments or from pelagic surface waters. The presence of a pelagic ecosystem during earliest Cambrian time seems reasonable, since phytoplankton-based food webs were built long before this. Abundant and diverse acritarchs are widespread in Lower Cambrian rocks, recording at least one stage in the life of pelagic organisms (Volkova et al., 1983; Yin, 1986; Knoll and Swett, 1987; Moczydłowska, 1991,1998; Yao et al., 2005).

\section{Summary}

Siliceous and phosphatic shales of the lower Cambrian Niutitang Formation in the Yangtiao section of Guizhou Province, south China, were deposited in a basinal setting beneath predominantly anaerobic water intermittently influenced by hydrothermal fluids. Sheet-like carbonaceous remains are abundantly preserved in Niutitang cherts, recording a hitherto unreported aspect of early Cambrian biological diversity. The new fossils remain problematic, but preserved characters suggest an interpretation as animal cuticle or peridermal tubes, perhaps sourced by early cnidarians that lived either as benthos in more proximal oxic environments or sank from nekton in overlying surface waters.

\section{Acknowledgements}

The work was supported by the National Natural Science Foundation of China (No. 40839910) and State Key Laboratory ofPalaeobiology and Stratigraphy (Nanjing Institute of Geology and Palaeontology, CAS (No.Y326150507). A. H. Knoll's research is supported by the NASA Astrobiology Institute, USA. We thank the reviewers for constructive comments and suggestions. 


\section{References}

Campesi, H. B., Farmer, J.D., Pichel, F.G., 2014. Modern terrestrial sedimentary biostructures and their fossil analogs in Mesoproterozoic subaerial deposits. PALAIOS 29 (2), 45-54

Bereiter-Hahn, J., A.G. Matoltsy, A.G., K.S. Richards, K.S.(eds.), 1984. Biology of the Integument 1: Invertebrates. Springer-Verlag, Heidelberg, 844 pp.

Boström, K., 1983. Genesis of ferromanganese deposits - diagnostic criteria for recent and old deposits. In (ed. Rona, P.A.): Hydrothermal process at seafloors Spring Centers. New York: Plenum Press, pp. 473-483.

Boström, K., Kraemer, T., Gartner, S., 1973. Provenance and accumulation rates of opaline silica, Al, Ti, Fe, Mn, Cu, Ni and Co in Pacific pelagic sediments. Chemical Geology11, 132-148.

Briggs, D.E.G., 2009. Molecular taphonomy of animal and plant cuticles: selective preservation and diagenesis. Philosophical Transactions of the Royal Society of London 354B, 7-17.

Cai, Y., Xiao, S., Hua, H., and Yuan, X., 2015. New material of the biomineralizing tubular fossil Sinotubulites from the late Ediacaran Dengying Formation, South China. Precambrian Research 261, 12-24.

Chapman, D.M., Werner, B., 1972. Structure of a solitary and a colonial species of Stephanoscyphus (Scyphozoa, Coronatae) with observations on periderm repair. Helgoländerwissenschaftliche Meeresuntersuchungen 23, 393-421.

Chen, Z. Bengtson, S. Zhou, C. M., Hua, H. and Yue, Z., 2008. Tube structure and original composition of Sinotubulites: shelly fossils from the late Neoproterozoic in southern Shaanxi, China.Lethaia, 41, 37-45.

Chen, D.Z., Wang, J.G., Qing, H.R., Yan, D.T. and Li, R.W., 2009. Hydrothermal activities in the Early Cambrian, South China: petrological, geochronological and stable isotopic constraints. Chemical Geology 258, 168-181.

Chen, D.Z., Zhou, X.Q., Fu, Y., Wang J.G., Yan. D.T., 2015. New U-P bzircon ages of the Ediacaran-Cambrian boundary strata in South China. Terra Nova 27(1), 62-68.

Cohen, P. A., Bradley, A., Knoll, A.H., Grotzinger, J.P., Jensen, S., Abelson, J.,Hand, K., Love, G., Metz, J., McLoughlin, N., Meister, P., Shepard, R., Tice,M., Wilson, J.P., 2009. Tubular Compression Fossils from the Ediacaran Nama Group, Namibia. Journal of Paleontology 83:110-122

Cortijo, I., Cai, Y., Hua, H., Schiffbauer, J. D., Xiao, S. H., 2015. Life history and autecology of an Ediacaran index fossil: Development and dispersal of Cloudina. Gondwana Research 28, 419-424.

Fan, D. L., Ye,J., Yang,R. Y., Huang,Z. X., 1987. The geological events and ore mineralization nearby the Precambrian一 Cambrian boundary in Yangtze Platform. Acta Sedimentologica Sinica 5(3), 81-95. (in Chinese, with English abstract)

Feng, L., Li, C., Huang, J., Chang, H.J., Chu, X.L., 2014. A sulfate control on marine mid-depth euxinia on the early Cambrian (ca. 529-521 Ma) Yangtze platform, South China. Precambrian Research 246, 123-133.

Gensel, P.G., 2008. The earliest land plants. Annual Review of Ecology Evolution and Systematics 39, 459-477.

Harvey, T. H. P. \& Pedder, B. E.,2013. Copepod mandible palynomorphs from the Nolichucky Shale (Cambrian, Tennessee): implications for the taphonomy and recovery of small carbonaceous fossils. PALAIOS 28, 278-284.

Harvey, T.H., Ortega-Hernández, J. Lin, J., Zhao, Y., Butterfield, N.J., 1999.Burgess Shale-type microfossils from the Middle 
Cambrian Kaili Formation, Guizhou Province, China.Acta Palaeontologica Polonica 57, 423-436.

Jarms, G., 1991. Taxonomic characters from the polyp tubes of coronate medusa (Scyphozoa, Coronatae). Hydrobiologia 216/217, 463-470.

Jiang, S.Y., Yang, J. H., Ling, H, F., Feng, H.Z., Chen, Y.Q., Chen, J.H., 2003. $\mathrm{Re}_{2} \mathrm{O}$ s isotopes and PGE geochemistry of black shales and intercalated Ni-Mo polymetallic sulfide bed from the Lower Cambrian Niutitang Formation, South China. Progress in Natural Science 13, 788-794.

Jiang, S.Y., Yang, J.H., Ling, H.F., Chen, Y.Q., Feng, H.Z., Zhao, K.D., Ni, P., 2007. Extreme enrichment of polymetallic NiMo-PGE-Au in Lower Cambrian black shales of South China: An Os isotope and PGE geochemical investigation. Palaeogeography, Palaeoclimatology, Palaeoecology 254,217-228.

Jones, B., Manning, D.A.C., 1994. Comparison of geochemical indices used for the interpretation of palaeoredox conditions in ancient mudstones. Chemical Geology 111, 111-129.

Knoll, A.H., 1985. Exceptional preservation of photosynthetic organisms in silicified carbonates and silicified peats. Philosophical Transactions of the Royal Society, London 311B, 111-122.

Knoll, A.H., Swett, K., 1987.Micropaleontology across the Precambrian/Cambrian boundary in Spitsbergen. Journal of Paleontology 61, 898-926.

Landing, E., Geyer, G., Brasier, M. D., Bowring, S. A., 2013. Cambrian Evolutionary Radiation: Context, correlation, and chronostratigraphy: Overcoming deficiencies of the first appearance datum (FAD) concept. Earth-Science Reviews 123, 133-172.

Li,S. R., Gao,Z. M., 1995. REE characteristics of black rock series of the lower Cambrian Niutitang Formation in Hunan-Guizhou provinces, China, with a discussion on the REE patterns in marine hydrothermal sediments. Acta Mineralogica Sinica 15, 225-229. (in Chinese, with English abstract)

Li, Y. F., Fan, T. L., Zhang, J. C., Zhang, J.P., Wei, X.J., Hu, X.L., Zeng, W.T., Fu, W., 2015. Geochemical changes in the Early Cambrian interval of the Yangtze Platform, South China: Implications for hydrothermal influences and paleocean redox conditions.Journal of Asian Earth Sciences 109, 100-123.

Liu, Y., Xiao, S., Shao, T., Broce, J., and Zhang, H., 2014, The oldest known priapulid-like scalidophoran animal and its implications for the early evolution of cycloneuralians and ecdysozoans. Evolution \& Development16, 155-165.

Luo, T.Y., Zhang, H., Li, X.B., Zhu, D., 2003. Mineralization characteristics of the multi-element-rich strata in the Niutitang Formation black shales, Zunyi, Guizhou, China. Acta Mineralogica Sinica, 23, 296-302. (in Chinese, with English abstract)

Lücking, R., Huhndorf, S., Pfister,D.H., Plata, E.R., Lumbsch, H.T. 2009. Fungi evolved on the right track. Mycologia 101, 810-822.

Moczydłowska, M., 1991.Acritarch biostratigraphy of the Lower Cambrian and the Precambrian-Cambrian boundary in southeastern Poland. Fossils and Strata 29, 1-127.

Moczydłowska, M., 1998. Cambrian acritarchs from Upper Silesia, Poland: biochronology and tectonic implications. Fossils 
and Strata 46,1-121.

Moczydłowska, M., Westall, F., Foucher, F., 2014.Microstructure and biogeochemistry of the organically preserved Ediacaran Metazoan Sabellidites. Journal of Paleontology 88, 224-239.

Morandini, A. C., Jarms, G., 2010. Identification of coronate polyps from the Arctic Ocean: Nausithoe werneri Jarms, 1990 (Cnidaria, Scyphozoa, Coronatae), with notes on its biology. Steenstrupia 32: 69-77.

Noffke. N., 2010.Geobiology: Microbial Mats in Sandy Deposits from the Archean Era to Today. Springer-Verlag, Heidelberg, 194 pp.

Pattan, J. N.,Pearce, N. J. G.,Mislankar, P. G., 2005. Constraints in using cerium-anomaly of bulk sediments as an indicator of paleobottom water redox environment: A case study from the Central Indian Ocean Basin. Chemical Geology 221, 260-278.

Pi, D. H., Liu, C. Q.,Shields-Zhou, Graham, A.,Jiang,S. Y., 2013.Trace and rare earth element geochemistry of black shale and kerogen in the early Cambrian Niutitang Formation in Guizhou Province, South China: Constraints for redox environments and origin of metal enrichments. Precambrian Research225, 218- 229.

Piper, D. Z., 1994. Seawater as the source of minor elements in black shales, phosphorites and other sedimentary rocks. Chemical Geology 117, 95-114.

Qian, Y.,Bengtson, S., 1989. Palaeontology and biostratigraphy of the early Cambrian Meishucunian Stage in Yunnan Province, south China. Fossils and Strata 24, 1-156.

Sarma, D. C. D., Raha, P. K., Moitra, A. K., Kumar, P. A., Anantharaman, S., Rao, M. R., Sundaram, V., 1992. Discovery of Precambrian-Cambrian transitional fossil sabelliditids from India. Current Science (Bangalore) 63, 140-142.

Sawaki, Y., Nishizawa, M., Suo, T., Komiya, T., Hirata, T., Takahata, N., Sano, Y., Han,J., Kon, Y., Maruyama, S., 2008. Internal structures and U-Pb ages of zircons from a tuff layer in the Meishucunian formation, Yunnan Province, South China. Gondwana Research 14, 148-158.

Scott, C., Lyons, T. W.,Bekker, A., Shen, Y.,Poulton, S. W., Chu X., Anbar, A. D., 2008.Tracing the stepwise oxygenation of the Proterozoic ocean. Nature 452, 456-459.

Smith, M.R., Harvey, T.H.P., Butterfield, N.J., 2015. The macro- and microfossil record of the Cambrian priapulid Ottoia. Palaeontology 58, 705-721.

Sokolov, B. S. 1965. The ancient deposits of lower Cambrian and sabelledtids. In: All-Union symposium on problem of Precambrian and Lower Cambrian, pp. 25-30 (In Russian).

Stankiewicz, B.A., Briggs, D.E.G., Evershed, R.P., 1997. Chemical composition of Paleozoic and Mesozoic fossil invertebrate cuticles as revealed by pyrolysis-gas chromatography/mass spectrometry. Energy and Fuels 11, 515-521.

Steiner, M., Wallis, E., Erdtmann, B.D., Zhao, Y.L., Yang, R.D., 2001. Submarine-hydrothermal exhalative ore layers in black shales from South China and associated fossils 3/4 insights into a Lower Cambrian facies and bio-evolution.Palaeogeography, Palaeoclimatology, Palaeoecology 169, 165-191.

Steiner, M., Zhu, M., Li, G., Qian, Y., Erdtmann, B.-D., 2004. New Early Cambrian bilaterian embryos and larvae from China: 
Geology 32, 833-836.

Steiner, M., Li, G. X., Qian, Y., Zhu, M. Y., Erdtmann, B.-D., 2007.Neoproterozoic to early Cambrian small shelly fossil assemblages and a revised biostratigraphic correlation of the Yangtze Platform (China). Palaeogeography, Palaeoclimatology, Palaeoecology 254, 67-99.

Stewart, S. E., Clarkson, E. N. K., Ahlgren, J., Ahlberg, P., Schoenemann, B., 2015.Sphenothallus from the Furongian (Cambrian) of Scandinavia. GFF 137, 20-24.

Taylor, S. R., McLennan, S. M., 1985. The continental crust: Its composition and evolution. Scientific American Publications, Palo Alto, California, 312 pp.

Taylor, S. R., McLennan, S. M., 1995. The geochemical evolution of the continental crust. Review of Geophysics 33, 241 265.

Urbanek, A., Mierzejewska, G., 1983. The fine structure of zooidal tubes in Sabelliditida and Pogonophora. In Urbanek, A. and Rozanov, A.Y. (eds): Upper Precambrian and Cambrian Palaeontology of the East-European Platform. Publishing House Wdawnictwa Geologiczne, Warsaw, pp. 100-111.

Urbancik, W., Bauer-Nebelsick, M., Ott, J. A., 1996. The ultrastructure of the cuticle of Nematoda. I. The body cuticle within the Stilbonematinae (Adenophorea, Desmodoridae). Zoomorphology 116: 51-64.

Vaniten, H., Muir, L.A., Botting,J.P., Y.D. Zhang, Y.D., Lin, J.-P., 2013. Conulariids and Sphenothallus (Cnidaria, Medusozoa) from the Tonggao Formation (Lower Ordovician, China). Bulletin of Geosciences 88, 713-722.

Volkova, N.A., Kiljanov, V.V., Piscun, L.V., Pashkyavichene, L.T., Jankauskas, T.V., 1983. Plant microfossils. In Keller, B.M., Rozanov, A.Y. (eds).Upper Precambrian and Cambrian Palaeontology of the East-European Platform. Publishing House Wdawnictwa Geologiczne, Warsaw, pp. 7-46.

Wang, Z. C., Fan, D. L., Chen,J. S., 1992. Origin of witherite ore deposits in early Cambrian Dabashan black shale series. ScientiaGeologicaSinica, No.3, 237-248

Werner, B. 1971. Stephanoscyphus planulophorus n. spec., ein neuer Scyphopolyp mit einem neuen Entwicklungsmodus. Helgoländerwissenschaftliche Meeresuntersuchungen 22, 120-140.

Yang, Q. H.,Zhang, Y. L., Zhen, W. W., Xu, X. S., 1980. Subdivision and correlation of Sinian Suberathem in Northern Jiangsu and Anhui. In: Research on Precambrian Geology-Sinian Suberathem in China. Tianjin Science and Technology Press, Tianjin, pp.231-265.

Yang, R.D., Zhu, L.J., Gao, H., Zhang, W. H., Jiang, L.J., Wang, Q., Bao, M.,2005. A study on characteristics of the hydrothermal vent and relating biota at the Cambrian bottom in Songlin, Zunyi County, Guizhou Province. Geological Review 5,481-492.(in Chinese, with English abstract)

Yao, J.X., Xiao, S.H., Yin, L.M., Li, G.X., Yuan, X.L., 2005. Basal Cambrian microfossils from the Yurtus and Xishanblaq formations (Tarim, North-West China): systematic revision and biostratigraphic correlation of Micrhystridium-like acritarchs. Palaeontology 48, 687-708.

Yin, L. M., 1986.Sinian microfossil plants from the Yangtze Gorges region. Journal of Stratigraphy 10, 262-269. (in Chinese, 
with English abstract)

Yin, L. M., 1997. Precambrian-Cambrian transitional acritarch biostratigraphy of the Yangtze Platform. Bulletin of National Museum of Natural Science (Taipei) 10, 217-231.

Zhao, Y. and Bengtson, S., 1999. Embryonic and post-embryonic development of the Early Cambrian cnidarian Olivooides. Lethaia 32, 181-195.

Zhou,C. M., Jiang, S. Y., 2009. Palaeoceanographic redox environments for the lower Cambrian Hetang Formation in South China : Evidence from pyrite framboids, redox sensitive trace elements , and sponge biota occurrence. Palaeogeography, Palaeoclimatology, Palaeoecology 271: 279 -286.

Zhang, H., Xiao, S., Liu, Y., Yuan, X., Wan, B., Muscente, A.D., Shao, T., Gong, H., and Cao, G., 2015. Armored kinorhynch-like scalidophoran animals from the early Cambrian: Scientific Reports 5, 16521, doi: 10.1038/srep16521.

Zhu, B., Jiang, S. Y., Yang, J. H., Pi, D. H., Ling, H. F., Chen, Y. Q., 2014. Rare earth element and Sr-Nd isotope geochemistry of phosphate nodules from the lower Cambrian Niutitang Formation, NW Hunan Province, South China. Palaeogeography, Palaeoclimatology, Palaeoecology 398, 132-143.

Zhu, R.X., Li, X.H., Hou, X.G., Pan, Y.X., Wang, F., Deng, C.L., He, H.Y., 2009. SIMS U-Pb zircon age of a tuff layer in the Meishucun section, Yunnan, southwest China: constraint on the age of the Precambrian-Cambrian boundary. Science in China Series D-Earth Sciences 52, 1385-1392. 







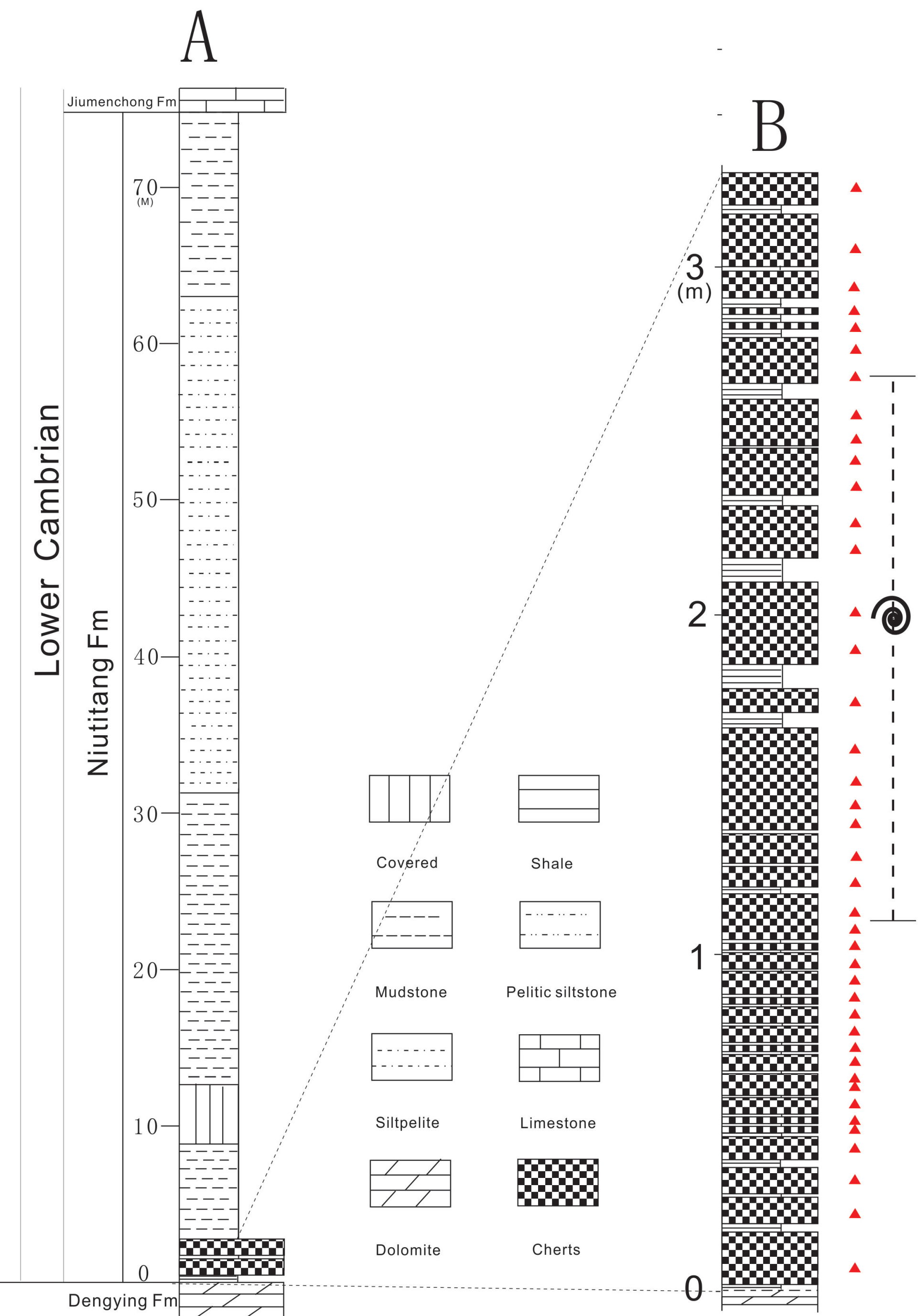




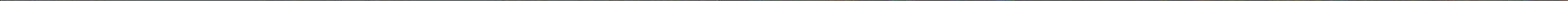




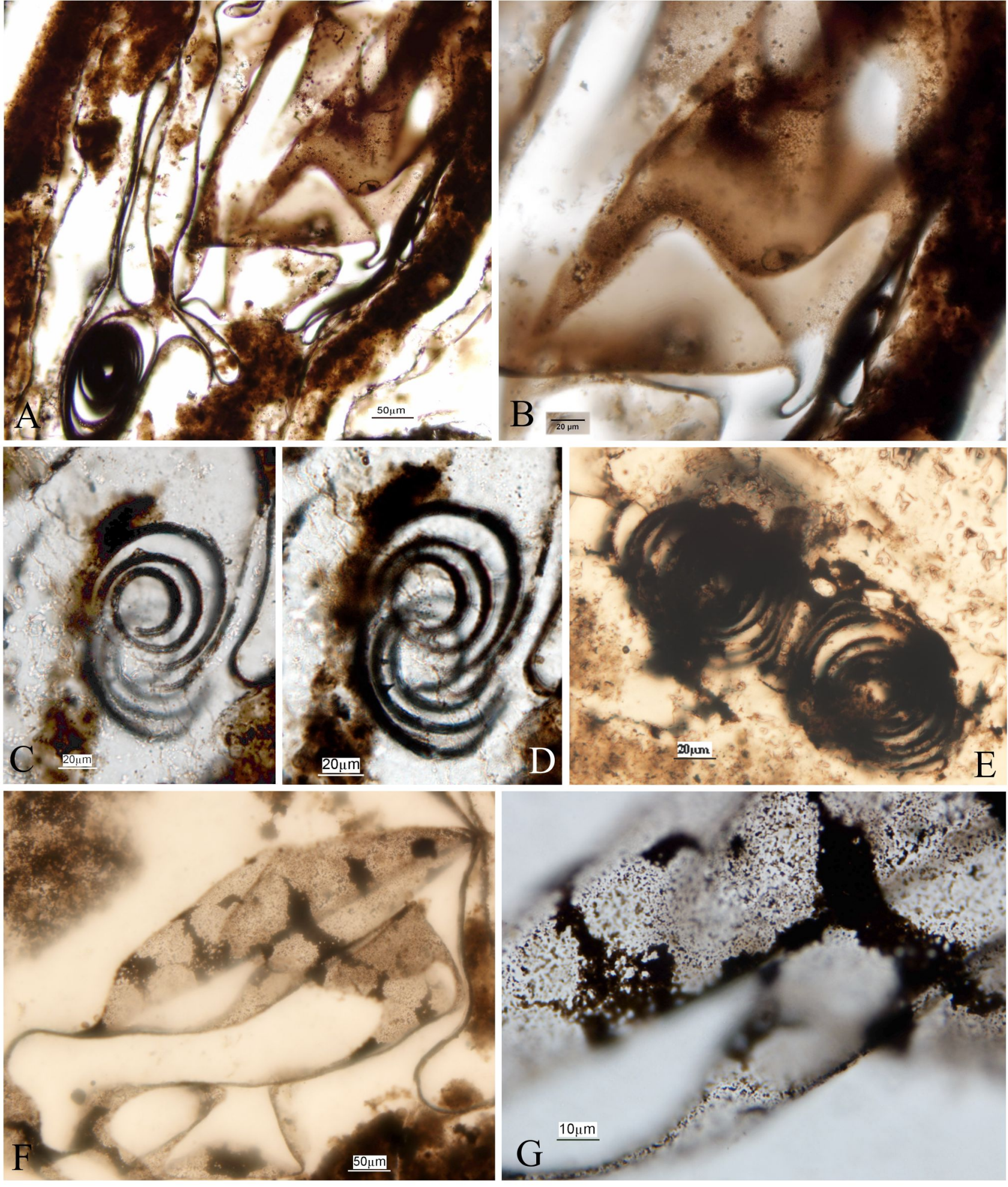




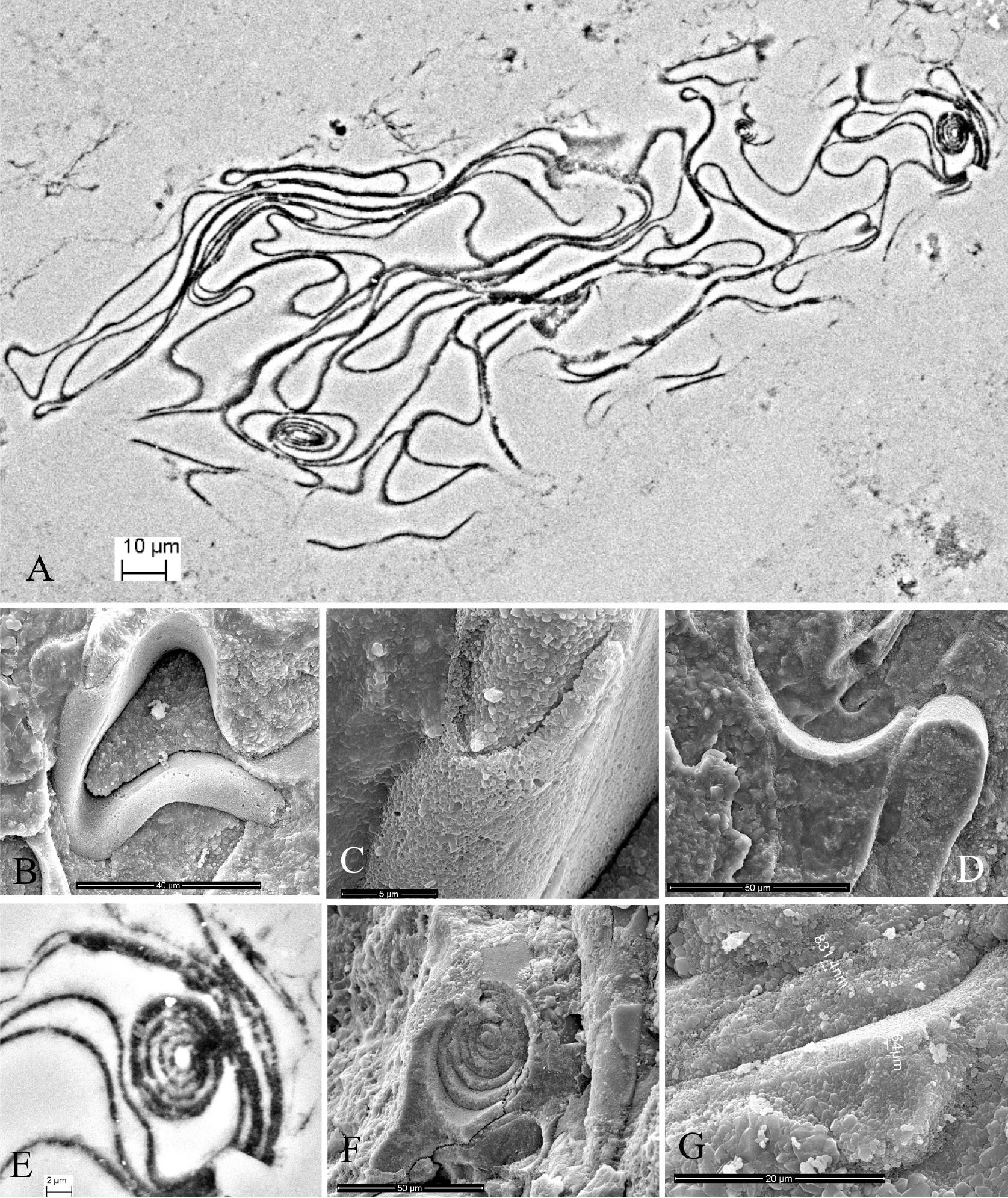




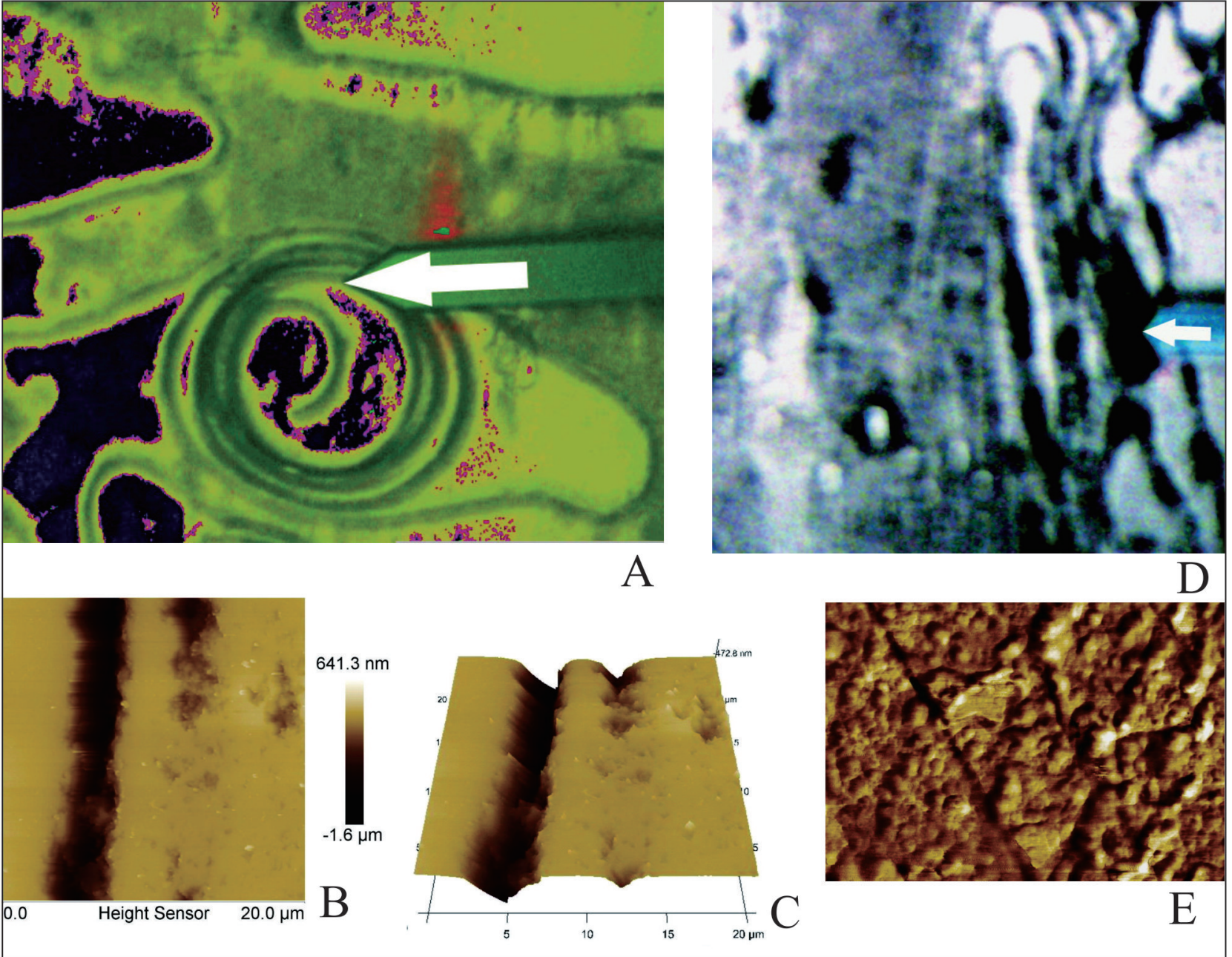




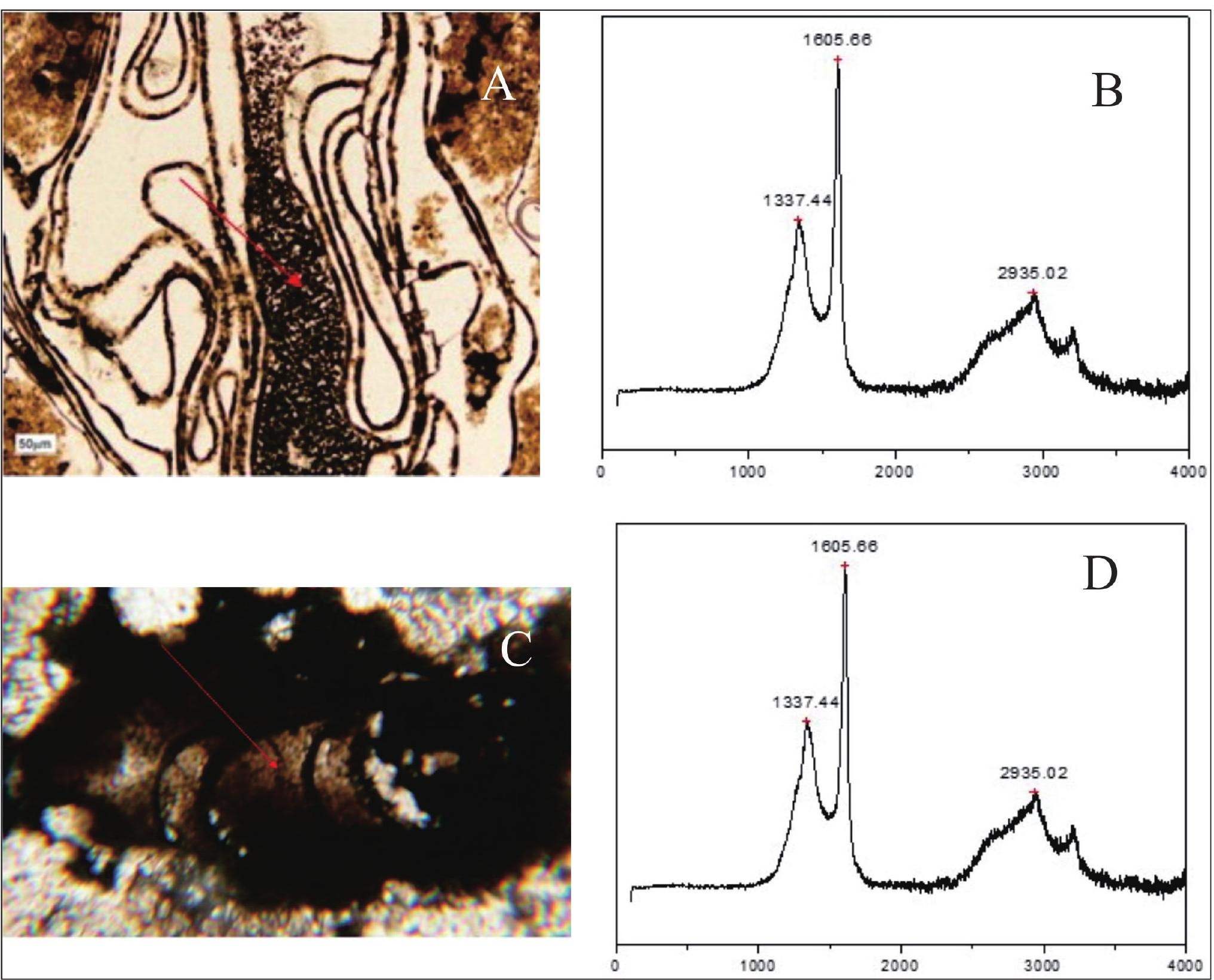

